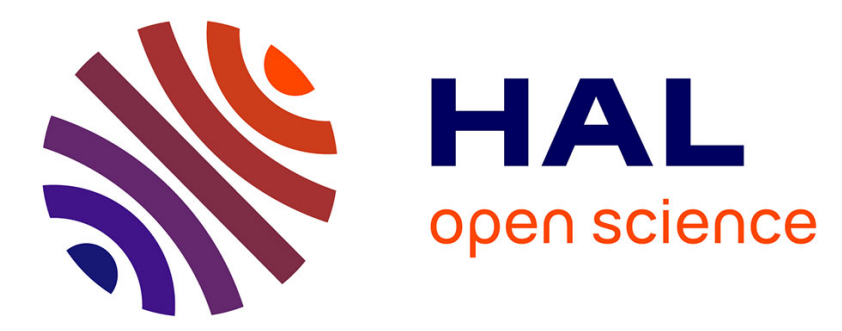

\title{
Modeling and Identification of Serial Robots
}

Wisama Khalil, Etienne Dombre

\section{To cite this version:}

Wisama Khalil, Etienne Dombre. Modeling and Identification of Serial Robots. ISTE Ltd, London. Robot Manipulators: Modeling, Performance Analysis and Control, pp.1-79, 2007, Control Systems, Robotics and Manufacturing Series, 978-1-905209-10-1. lirmm-00127734

\section{HAL Id: lirmm-00127734 https://hal-lirmm.ccsd.cnrs.fr/lirmm-00127734}

Submitted on 29 Jan 2007

HAL is a multi-disciplinary open access archive for the deposit and dissemination of scientific research documents, whether they are published or not. The documents may come from teaching and research institutions in France or abroad, or from public or private research centers.
L'archive ouverte pluridisciplinaire HAL, est destinée au dépôt et à la diffusion de documents scientifiques de niveau recherche, publiés ou non, émanant des établissements d'enseignement et de recherche français ou étrangers, des laboratoires publics ou privés. 
This book presents the most recent research results about the modeling and control of robot manipulators.

- Chapter 1 gives unified tools to derive direct and inverse geometric, kinematic and dynamic models of serial robots and addresses the issue of identification of the geometric and dynamic parameters of these models.

- Chapter 2 describes the main features of parallel robots, the different architectures and the methods used to obtain direct and inverse geometric, kinematic and dynamic models paying special attention to singularity analysis.

- Chapter 3 introduces global and local tools for performance analysis of serial robots.

- Chapter 4 presents an original optimization technique for point-to-point trajectory generation accounting for the robot dynamics.

- Chapter 5 presents standard control techniques in the joint space and task space for free motion (PID, computed torque, adaptive dynamic control, and variable structure control), and constrained motion (compliant force-position control).

- In chapter 6, the concept of vision-based control is developed and Chapter 7 is devoted to specific issue of robots with flexible links. Efficient recursive Newton-Euler algorithms for both inverse and direct modeling are presented, as well as control methods ensuring position setting and vibration damping.

Etienne Dombre is Director of Research at the National Centre for Scientific Research (CNRS). He is with the Robotics Department of the Laboratoire de Recherche en Informatique, Robotique et Microélectronique de Montpellier (LIRMM), France.

Wisama Khalil is Professor at the Ecole Centrale at Nantes, France. He is with the Robotics Department of the Institute of Research in Communication and Cybernetics of Nantes. 